\title{
Modal Deoxyribonucleic Acid Value and Survival in Carcinoma of the Breast
}

\author{
N. B. ATKIN
}

British Medical fournal, 1972, 1, 271-272

\section{Summary}

On the basis of their modal deoxyribonucleic acid values, 67 carcinomas of the breast fell into two discrete groups. The lower (near-diploid) group showed a significantly better eightyear survival rate than the higher (triploid-tetraploid) group. The four-year survival rates of $\mathbf{4 0}$ further cases classified in the same way showed similar trends.

\section{Introduction}

Suitable techniques for the chromosome analysis of human tumours have been available for only a few years, so that long-term follow-up studies on the relationship between chromosome complement and outcome of treatment are not yet possible. Even now, these techniques are by no means always successful, and it is difficult or impossible to obtain data on unselected series of cases. These considerations do not apply to the microspectrophotometric determination of deoxyribonucleic acid (DNA) content, a technique which can confidently provide an estimate of the approximate chromosome number of a sample of tumour tissue (Atkin et al., 1966).

In this report evidence is provided for a relationship between modal chromosome number, estimated from DNA data, and survival in carcinoma of the breast, based on the eight-year survival rate of 67 patients and the four-year survival rate of $\mathbf{4 0}$ further patients.

\section{Materials and Methods}

The DNA contents of individual cells were estimated on smears prepared from tissue from the untreated primary tumours obtained at operation. Smears were fixed by freezesubstitution and stained by the Feulgen method, measurements being made with the integrating microdensitometer designed by Deeley (1955) as previously described (Atkin and Richards, 1956). From the distribution of DNA contents

Department of Cancer Research, Mount Vernon Hospital, Northwood, Middlesex

N. B. ATKIN, M.B., B.CH., D.M.R.T., Cytogeneticist

for each specimen a mode was derived as in previous studies (Atkin et al., 1966). Each mode was expressed in arbitrary units, a value of 100 being ascribed to the mean of the control cells (leucocytes and fibroblasts in the tumour tissue); in view of the $10 \%$ higher DNA value of epithelial cells as compared with leucocytes and fibroblasts (Atkin and Richards, 1956, Atkin et al., 1966) the expected value for normal (diploid) epithelial cells is 110 .

Nearly all cases were treated primarily by surgery, or by surgery followed by radiotherapy to the chest wall and regional lymph node areas.

\section{Results}

The modal DNA values of 67 tumours in terms of eight-year survival are shown in the chart. In Table $I$ the cases are further classified according to clinical stage. It is apparent that they fall into two main groups and that those in the lower (near-diploid) group have shown a better response than those in the higher group, which extends from just below the triploid to a little above the tetraploid level, most tumours,

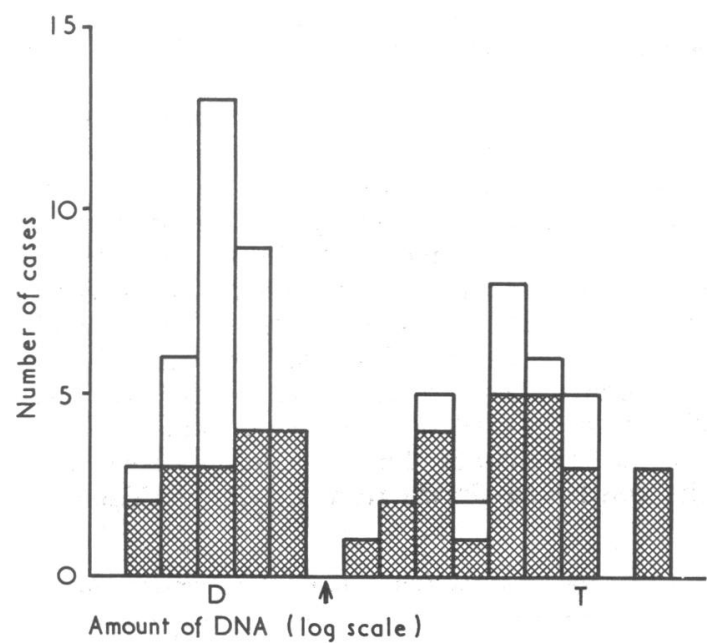

Modal DNA values of 67 carcinomas of the breast. Shaded: died within eight years. Clear: survived eight years. D and T: diploid and tetraploid epithelial DNA values respectively. The arrow indicates a DNA value corresponding to about 58 chromosomes.

TABLE I-Eight-year Survival of 67 Patients with Carcinoma of Breast, according to Modal DNA Value and Clinical Stage

\begin{tabular}{|c|c|c|c|c|c|c|c|c|c|c|c|c|c|c|c|c|}
\hline \multirow{4}{*}{$\begin{array}{c}\text { Clinical } \\
\text { Stage } \\
\text { (Inter- } \\
\text { national } \\
\text { System, } \\
\text { Portmann, } \\
\text { 1954) } \\
\end{array}$} & \multicolumn{16}{|c|}{ Modal DNA Value in Arbitrary Units } \\
\hline & \multicolumn{5}{|c|}{ Classes Constituting the Near-diploid Group } & \multirow[b]{2}{*}{ 133- } & \multicolumn{10}{|c|}{ Classes constituting the Triploid-tetraploid Group } \\
\hline & 90- & 101- & 108- & 116- & 124- & & 143- & 153- & 164 & 175- & 188- & 201- & 216 & 231- & $247-263$ & Total \\
\hline & Alive Died & A. D. & A. D. & A. D. & A. D. & A. $\mathbf{D}$. & A. D. & A. D. & A. D. & A. D. & A. D. & A. D. & A. D. & A. D. & A. D. & A. D. \\
\hline $\begin{array}{ll}\text { II } & . . \\
\text { III } & \ldots \\
\text { IV } & . . \\
\end{array}$ & $\begin{array}{ll}\frac{1}{1} & \frac{1}{1} \\
- & -\end{array}$ & $\begin{array}{ll}1 & 1^{*} \\
1 & 1 \\
1 & \frac{1}{1} \\
\end{array}$ & $\begin{array}{l}6+3 \ddagger \\
2 \dagger= \\
2-= \\
-=\end{array}$ & $\begin{array}{l}33^{*} \\
1+1 \\
1 \dagger \\
-\end{array}$ & $\begin{array}{l}\bar{y} \\
\bar{z} \\
\overline{-}\end{array}$ & $\begin{array}{l}\bar{z} \\
\bar{z}\end{array}$ & $\begin{array}{l}=1 \\
\bar{z}\end{array}$ & $\begin{array}{l}\bar{z} \\
\bar{z} \\
\bar{z}\end{array}$ & $\begin{array}{l}1 \\
=\frac{3}{1}\end{array}$ & $\begin{array}{l}1 \\
\overline{1} \\
\overline{-}\end{array}$ & $\begin{array}{ll}2 & 4^{*} \\
1 & 1 \\
- & -\end{array}$ & $\begin{array}{l}\overline{1} 4^{*} \\
\overline{-} \\
-\end{array}$ & $\begin{array}{ll}1 & \overline{2} \\
1 & 2 \\
- & 1\end{array}$ & $\begin{array}{l}\bar{z} \\
\bar{z} \\
\bar{z}\end{array}$ & $\begin{array}{l}=2 \\
=1 \\
=-\end{array}$ & $\begin{array}{rr}16 & 21 \\
7 & 15 \\
4 & 2 \\
- & 2\end{array}$ \\
\hline Total & 122 & 33 & 103 & 54 & -4 & - & -1 & -2 & $\begin{array}{ll}1 & 4\end{array}$ & 11 & 35 & 15 & & -- & -3 & 2740 \\
\hline
\end{tabular}

Near-diploid group: total alive 19, total died 16. Triploid-tetraploid group: total alive 8, total died 24. 
however, being hypertriploid or hypotetraploid (the arrow in the chart, placed in the interval between the two groups, corresponds to a chromosome number of about 58). Thus 19 out of $35(54 \%)$ in the lower group have survived eight years as compared with 8 out of $32(25 \%)$ in the higher group, a difference which is significant at the $5 \%$ level $\left(x^{2}=5 \cdot 96\right)$.

From Table $I$ it does not appear that the difference in survival rate between the two groups is related to the clinical stage of the cases. A comparison of the groups with respect to other data is shown in Table II. The data on degree of differentiation and incidence of axillary lymph node meta-

TABLE II-Comparison of the Two Groups with Known Eight-year Survival Rates

\begin{tabular}{|c|c|c|c|c|c|c|c|}
\hline & \multirow{2}{*}{$\begin{array}{c}\text { Mean } \\
\text { Age } \\
\text { (and } \\
\text { Standard } \\
\text { Devia- } \\
\text { tion) }\end{array}$} & \multicolumn{3}{|c|}{$\begin{array}{c}\text { Histological } \\
\text { Differentiation }\end{array}$} & \multicolumn{3}{|c|}{$\begin{array}{l}\text { Metastases in Axillary } \\
\text { Lymph Nodes on } \\
\text { Histological Eramination }\end{array}$} \\
\hline & & Good & \begin{tabular}{|l|} 
Moderate \\
or \\
"Average"
\end{tabular} & Poor & Present & Absent & $\begin{array}{c}\text { Not } \\
\text { Examined }\end{array}$ \\
\hline Lower (near-diploid) & $\begin{array}{c}58 \cdot 4 \\
(+12 \cdot 2)\end{array}$ & 3 & 28 & 4 & 17 & 13 & 5 \\
\hline $\begin{array}{l}\text { Higher (triploid- } \\
\text { tetraploid) group }\end{array}$ & $\begin{array}{c}60 \cdot 6 \\
( \pm 12 \cdot 8)\end{array}$ & 0 & 27 & 5 & 18 & 6 & 8 \\
\hline
\end{tabular}

stases do not allow any firm conclusions to be drawn $\left(x^{2}=\right.$ 3.00 and 3.17 respectively; $0.30>P>0.20$ ). Perhaps the better prognosis of the cases in the lower group is related to a lower frequency of lymph node metastasis, but this would need verification from a larger series of cases.

To determine whether a similar survival pattern exists for more recently treated cases, a further series of 40 patients whose four-year survival rate is known has been studied. Unlike the first series of 67 cases, which is considered to approximate to an unselected series of breast carcinomas subjected to surgical treatment or biopsy, measurements have not yet been made on all the more recent cases that are available for study, and this series is unbalanced since it includes a relatively high proportion of patients who have died as well as those who were part of a separate study in which chromosome numbers and DNA values were compared. Nevertheless, this group of 40 patients is useful in providing further evidence for a relationship between DNA value and outcome of treatment. The tumours again fall into two discrete groups showing a difference in survival rate which is not significant in itself $\left(\chi^{2}=0.50\right)$ but which, being in the same direction as that of the main group of 67 cases, reinforces the conclusion drawn from the latter (Table III).

TABLE III-Comparison in 40 Patients with Known Four-year Survival Rate

\begin{tabular}{ll|c|c}
\hline & & Survived Four Years & Died within Four Years \\
\hline $\begin{array}{l}\text { Near-diploid group } \\
\text { Triploid-tetraploid group }\end{array}$ & $\ldots$ & 7 & 4 \\
\hline
\end{tabular}

\section{Discussion}

When assessed histologically carcinoma of the breast can be classified into groups, each of which has an overall prognosis that may be better or worse than average. Within each group, however, individual cases show a wide variation in their response to treatment (Schiødt, 1967). It is desirable, therefore, that additional prognostic criteria be sought; cytogenetic criteria may fill this need. Though the possible value of a complete karyotype evaluation in the prognosis of tumours is at present uncertain there is evidence that the chromosome number, as estimated from DNA measurements on interphase cells, may be of prognostic value in several forms of cancer. In squamous cell carcinoma of the cervix near-tetraploid tumours have the best prognosis (Atkin, 1971a); in the corpus uteri (Atkin, 1971a) and ovary (Atkin, 1971b), near-diploid tumours are, however, more favourable and evidence is here presented that the same is true of carcinoma of the breast. Possibly, near-diploid adenocarcinomas as a whole have a relatively favourable prognosis, whereas for squamous cell carcinomas near-tetraploid tumours are more favourable.

To what extent the difference in prognosis is related to degree of differentiation is uncertain, though it seems that at the sites previously studied, and in the breast, if there is a relationship it is not very strong. Cytogenetic criteria can, it seems, provide evidence relating to prognosis which is additional to that obtainable from histological studies and, moreover, has the merit of greater objectivity.

Histological methods of grading have been used in carcinoma of the breast in which the size of the nuclei is taken into account. In Greenough's system (Greenough, 1925; Patey and Scarff, 1928; Bloom and Richardson, 1957) the degree of nuclear pleomorphism is assessed: the greater the variation in size, shape, and staining of the nuclei, the worse the prognosis. This variation might be correlated with the occurrence of polyploidization in the tumour cell population, but would not seem to be related to the basic modal chromosome number. Friedell (1969) used a system of nuclear grading which takes account of the overall size of the nuclei, tumours in the grade with small nuclei (therefore perhaps near-diploid) having a favourable prognosis.

The assessment of the sex chromatin content of tumour cells may also be of prognostic value. It has been found that tumours of females that are near-diploid generally show sex chromatin whereas high-ploidy tumours do not, though there are numerous exceptions (Atkin, 1960); a more favourable prognosis has been found for those carcinomas of the breast which show a high incidence of tumour cells with sex chromatin (Wacker and Miles, 1966; Kallenberger et al., 1968).

The question of consistency of chromosome number and DNA value in different regions of the same tumour is at present receiving study. Preliminary results suggest that a minority of tumours of the breast show variation, this usually taking the form of near-diploid and near-tetraploid (rather than near-triploid) modes in different regions.

It is to be hoped that full karyotype studies will provide a still better guide to prognosis in carcinoma of the breast. Perhaps those near-diploid tumours with the best prognosis will prove to have minimal chromosome changes such as single trisomies, as may be true for carcinoma of the corpus uteri (Baker, 1968).

I thank the staffs of the surgical, radiotherapeutic, and pathological departments of Mount Vernon Hospital for their kind co-operation, and Mrs. C. T. Elledge for secretarial services. This work was supported by a grant from the Cancer Research Campaign.

\section{References}

Atkin, N. B. (1960). Acta Unio Internationalis contra Cancrum, 16, 41. Atkin, N. B. (1971a). In Modern Radiotherapy: Gynaecological Cancer, ed. T. J. Deeley, p. 138. London, Butterworths.

Atkin, N. B. (1971b). Cancer, 27, 1064. Atkin, N. B., Mattinson, G., and Baker, M. C. (1966). British fournal of Atkin, N. B., and Richards, B. M. (1956). British fournal of Cancer, 10,

Bloom, H. J. G., and Richardson, W. W. (1957). British fournal of Cancer, $11,359$.

Deeley, E. M. (1955). Fournal of Scientific Instruments, 32, 263.

Friedell, G. H. (1969). New York State Fournal of Medicine, 69, 2766

Greenough, R. B. (1925). Fournal of Cancer Research, 9, 453. Kallenberger, A., Hagmann, A., and Descoeudres, C. (1968). European

Fournal of Cancer, $3,439$.
Patey, D. H., and Scarff, R.

Patey, D. H., and Scarff, R. W. (1928). Lancet, 1, 801.

Portmann, U. (1954). Acta Radiologica, Suppl. No. 116, p. 718

Schiфdt, T. (1967). Danish Medical Bulletin, 14, 239.

Wacker, B., and Miles, C. P. (1966). Cancer, 19, 1651. 